\title{
RPS6KB2 wt Allele
}

National Cancer Institute

\section{Source}

National Cancer Institute. RPS6KB2 wt Allele. NCI Thesaurus. Code C51175.

Human RPS6KB2 wild-type allele is located in the vicinity of 11q13.1 and is approximately

$7 \mathrm{~kb}$ in length. This allele, which encodes ribosomal protein 56 kinase 2 protein, plays a role in protein synthesis via the phosphorylation of ribosomal protein 6. The RPS6KB2 gene is overexpressed in certain cancers such as adenocarcinomas of the breast and endometrium. 